\title{
Acute Lymphoblastic Leukemia Complicating Graves' Disease in a Sudanese Adolescent Girl: A Case Report and Exploration of the Underlying Mechanism Possibilities
}

Ghassan Faisal Fadlalbari ( $\sim$ ghasso81@gmail.com )

Gaafar Ibn Auf Pediatric Tertiary Hospital https://orcid.org/0000-0003-0823-1682

\section{Samar Sabir Hassan}

Gaafar Ibn Auf Pediatric Tertiary Hospital

Asmahan T Abdallah

Sudan Childhood Diabetes Center

\section{Samar Omer Abusamra}

Sudan Childhood Diabetes Center

Abeer Mohamed Abdalrhman

Gaafar Ibn Auf Pediatric Tertiary Hospital

Mohamed Ahmed Abdullah

University of Khartoum Faculty of Medicine

\section{Case report}

Keywords: Graves' Disease, Acute lymphoblastic Leukemia, Adolescent, Sudan

Posted Date: August 18th, 2021

DOI: https://doi.org/10.21203/rs.3.rs-792497/v1

License: (c) (i) This work is licensed under a Creative Commons Attribution 4.0 International License.

Read Full License 


\section{Abstract}

Background. Graves' Disease (GD) related bone marrow injury presents usually as agranulocytosis or less commonly as pancytopenia. However, acute lymphoblastic leukemia (ALL) has been reported recently in an adult patient with GD. The underlying pathogenesis is not fully understood. Nevertheless, the harmful effect of anti-thyroid drugs or autoimmune reaction to bone marrow cells is anticipated to be the causative factors.

Case report. A 16.5-year-old Sudanese girl with GD was on carbimazole for the first fourteen months of her illness, with irregular follow up, then it was withdrawn because she developed hypothyroidism for which she was put on thyroxine. Meanwhile, she developed severe anemia without fever which necessitated blood transfusion. Eight months later, she presented with thyrotoxicosis relapse, febrile illness and pancytopenia which was proved to be ALL on bone marrow examination.

Conclusion: ALL must be considered when encountering a GD patient with pancytopenia.

\section{Background}

Graves' Disease (GD) is an autoimmune condition that results in hyperthyroidism [1]. Most children and adolescents with GD are started on anti-thyroid drugs (ATD) as the first line of treatment [2]. Though rare, bone marrow injury (BMI) is a critical complication of GD. Data on its prevalence among children is lacking, however it is estimated to be lower than the $0.3 \%$ that has been reported in adults $[2,3]$. GD related BMI usually manifests as agranulocytosis or, less commonly, as pancytopenia when more than one marrow cell lines are injured $[3,4]$. We herein report an adolescent girl with GD complicated by acute lymphoblastic leukemia (ALL).

\section{Case Report}

A 16.5-year-old female was diagnosed to have GD following presentation with fatigability, weight loss, nervousness, tremors, delayed puberty, diffuse goiter and exophthalmos. The hyperthyroid status was confirmed biochemically as Thyroid Stimulating Hormone (TSH) was suppressed, free thyroxine (FT4) and free tri-iodothyronine (FT3) were elevated. Antibody testing for thyroid receptor and anti-thyroid peroxidase were not done due to the resources constraints. The presence of exophthalmos supported the clinical diagnosis of GD. Baseline Complete Blood Count (CBC) and liver function tests were normal (Table 1). She was commenced on carbimazole $10 \mathrm{mg} \mathrm{BID}$ and propranolol $10 \mathrm{mg}$ TDS. The patient and her family were counseled about the therapy side effects and clear instructions were provided. She was then referred to be under the care of the nearby pediatrician.

She continued to follow up for the initial few months, then she dropped to do so though was adherent to her medication. Fourteen months later, she presented to the local hospital with shortness of breath and right hypochondrial pain. She was found to be very pale with anemic heart failure which necessitated an urgent blood transfusion and was then referred to the regional Pediatric Hospital. The patient and her 
family denied any history of bleeding, fever, bone pain or jaundice at that time. Further workup there revealed that she was hypothyroid (Table 1). Therefore, levothyroxine was started after carbimazole withdrawal. Unfortunately, $\mathrm{CBC}$ and blood biochemistry results were lost but no bone marrow examination was done. After five days, she was discharged home in a better condition and referred back to the local hospital for further follow-up. Unfortunately, she was not consistent to follow up and was not adherent to her medication (levothyroxine).

Eight months later, she was admitted again to the local hospital with a history of high grade fever, fatigue and bone pain for two weeks and was found to have severe anemia. She received blood transfusion, intravenous wide-spectrum antibiotics and was referred to our facility for further management. On arrival, she was cachexic, thyrotoxic with tachycardia, large collapsing pulse, wet warm hands, tremors, diffuse goiter and exophthalmos. In addition, she had cervical lymphadenopathy, parotid enlargement, fever, tender hepatomegaly, no splenomegaly and generalized bone tenderness. She was wasted (Body Mass Index -5.5 SDS), short (-3.8 SDS) and pre-pubertal. Laboratory investigations showed pancytopenia, atypical lymphocytes on peripheral film, thyrotoxicosis, elevated C-reactive protein and negative Ebstein Barr virus serology (Table 1). Renal and liver function tests as well as urinalysis and serum uric acid were normal. She was started on propranolol, intravenous wide-spectrum antibiotics, intravenous fluid and antipyretics for which she showed some improvement.

After consultation with a hematologist, a bone marrow examination was performed. It showed a hypercellular marrow, reduced megakaryocytes, depressed erythroid series and $80 \%$ infiltration with blast cells which were consistent with ALL. The patient was then transferred to the oncology unit for further management. Unfortunately, she passed away after initiation of chemotherapy with complications of tumor lysis syndrome.

\section{Discussion And Conclusions}

GD is an uncommon thyroid disorder in children, though its incidence is believed to be increasing [5]. If it is not managed, thyrotoxicosis may lead to cachexia, osteoporosis, cardiac arrhythmias, embolism and rarely cardiovascular failure and death [2].

Although there is a variation in the approach of managing childhood GD among practitioners, ATDs remain the first option for many of them [2]. Adverse effects were recorded in up to $20 \%$ of children and adolescents treated with ATDs $[6,7]$. The majority of them had minor musculoskeletal or skin reactions. The most serious reported complication of carbimazole therapy is the development of agranulocytosis/pancytopenia which was estimated to be very rare in the pediatric population [2]. It commonly occurs within three months after the therapy initiation. In Nakamura $\mathrm{H}$ et al study, more than $80 \%$ of 754 adults with methimazole-induced agranulocytosis developed the condition within 90 days of starting the drug [8]. Methimazole induced hepatocellular injury and ANCA-positive vasculitis are rather rarer documented complications in young population $[9,10]$. In Watanabe et al study, 54 out of 55 patients with ATD-induced agranulocytosis/pancytopenia recovered to granulocyte colony stimulating factor, 
dexamethasone or supportive measures within 21 days. However, one patient with pancytopenia remained resistant to treatment [3].

Our patient had severe anemia during the course of her illness which was not associated with features suggestive of other marrow cell line insult i.e. bleeding or fever. In an adult based GD study, isolated anemia was detected in 33\% of them [11]. GD being an autoimmune disease, anemia in GD patients may be secondary to a comorbid autoimmune condition such as autoimmune hemolytic anemia, pernicious anemia or celiac disease [12]. Our patient was not tested for these however, she had no signs consistent with either of them i.e, jaundice, abdominal distention or macrocytosis (Table 1). But their absence does not exclude the definite presence of this comorbidity.

The exact underlying mechanism of GD related BMI is still not well recognized. The cytotoxic effect of the ATDs or the autoimmune reaction on the bone marrow antecedents are postulated to be possible pathogenic factors [13]. The later hypothesis might be emphasized by the detection of anti-granulocyte antibodies in some of those who received ATD [8]. In vitro, it has been shown that the lymphocytes of agranulocytic patients have the risk of transformation to blast cells if exposed to ATD [14]. Nehara HR et al have lately reported a young adult male with GD and pancytopenia who developed ALL four months after re-exposure to carbimazole [13]. That is in contrast to our patient who withdrew the carbimazole eight months before developing the ALL. But we are not sure if the leukemic process started earlier.

Ironically, it has recently been argued that ATDs can help in the management of pancytopenia.

Scappaticcio $L$ et al have described 29 untreated GD patients with pancytopenia as a presenting feature, none of them had blast cells on bone marrow examination. Around $90 \%$ of those who received ATD showed normalization of blood cells counts [15]. This suggests that thyrotoxicosis itself may play a role in the pathogenesis of GD related BMI. An assumption which may be supported by the recurrence of pancytopenia when there is a relapse of the thyrotoxicosis $[16,17,18,19]$.

To the best of our knowledge, this is the first case report of ALL complicating GD as an unprecedented kind of BMI in this age group. In our patient, it seems that the prolonged uncontrolled hyperthyroid environment or the prolonged use of ATD without follow up were likely risk factor for her BMI and development of ALL. Further studies to see the relation between GD and ALL cannot be denied. All patients should be watched for this serious complication particularity when there is pancytopenia, bone pain or pancytopenia not responding to treatment.

\section{Abbreviations}

ALL: Acute lymphoblastic leukemia, ATD: Anti-thyroid drug, BMI: Bone marrow injury, CBC: Complete blood count, FT3: Free tri-iodothyronine, FT4: Free thyroxine, GD: Graves' disease, TSH: Thyroidstimulating hormone.

\section{Declarations}


Acknowledgements:

Authors would like to thank the patient's family for giving consent for this paper.

\section{Author contributions:}

GFF drafted the initial manuscript. GFF, SSH, ATA, AMA, SOA and AMA were involved in data acquisition. MAA critically revised the paper. All authors approved the final manuscript.

\section{Funding:}

No funding was received for this article.

\section{Availability of data and materials:}

All data are included in this manuscript.

\section{Ethics approval and consent to participate:}

Clinical data of the case was approved by the hospital ethics committee

\section{Consent for publication:}

Written informed consent was obtained from parents. The signed consent form is available on request.

\section{Competing interests:}

The authors declare that they have no competing interests.

\section{References}

1. Wasniewska M, Corrias A, Salerno M, Lombardo F, Aversa T, Mussa A, et al. Outcomes of children with hashitoxicosis. Horm Res Paediatr. 2012;77:36-40. https://doi.org/10.1159/000334640.

2. Ross DS, Burch HB, Cooper DS, Greenlee MC, Lauberg P, Maia AL, et al. 2016 American thyroid association guidelines for diagnosis and management of hyperthyroidism and other causes of thyrotoxicosis. Thyroid. 2016;26:1343-421. https://doi.org/10.1089/thy.2016.0229.

3. Watanabe N, Narimatsu H, Noh JY, Yamaguchi T, Kobayashi K, Kami M, et al. Antithyroid drug-induced hematopoietic damage: A retrospective cohort study of agranulocytosis and pancytopenia involving 50,385 patients with Graves' disease. J Clin Endocrinol Metab. 2012; 97:49-53. https://doi.org/10.1210/jc.2011-2221.

4. Psomadakis C, Creamer A, Baynes C. Carbimazole-induced pancytopaenia. Br J Hosp Med (Lond). 2016;77:248-9. https://doi.org/10.12968/hmed.2016.77.4.248.

5. Leger J. Graves' disease in children. Paediatric thyroidology. 2014;26:171-82. https://doi.org/10.1159/000363163. 
6. Kourime M, McGowan S, Al Towati M, Ahmed F, Stewart G, Williamson S, et al. Long-term outcome of thyrotoxicosis in childhood and adolescence in the west of Scotland: the case for long-term antithyroid treatment and the importance of initial counselling. Arch Dis Child. 2018;103:63742. https://doi.org/10.1136/archdischild-2017-314486.

7. Rabon S, Burton AM, White PC. Graves' disease in children: Iong-term outcomes of medical therapy. Clin Endocrinol. 2016;85:632-5. https://doi.org/10.1111/cen.13099.

8. Nakamura H, Miyauchi A, Miyawaki N, Imagawa J. Analysis of 754 cases of antithyroid drug-induced agranulocytosis over 30 years in Japan. J Clin Endocrinol Metab. 2013;98:4776-83. https://doi.org/10.1210/jc.2013-2569.

9. Rivkees SA, Mattison DR. Propylthiouracil (PTU) Hepatoxicity in Children and Recommendations for Discontinuation of Use. Int J Pediatr Endocrinol. 2009 Dec;2009:1-8. https://doi.org/10.1155/2009/132041.

10. Wada N, Mukai M, Kohno M, Notoya A, Ito T, Yoshioka N. Prevalence of serum anti-myeloperoxidase antineutrophil cytoplasmic antibodies (MPO-ANCA) in patients with Graves' disease treated with propylthiouracil and thiamazole. Endocr J. 2002;49:329-34. https://doi.org/10.1507/endocrj.49.329.

11. Gianoukakis AG, Leigh MJ, Richards P, Christenson PD, Hakimian A, Fu P, et al. Characterization of the anaemia associated with Graves' disease. Clin Endocrinol. vol. 2009;70:781-7. https://doi.org/10.1111/j.1365-2265.2008.03382.x.

12. Hegazi MO, Ahmed S. Atypical clinical manifestations of graves' disease: an analysis in depth. J Thyroid Res. 2012 Jan 1;2012. https://doi.org/10.1155/2012/768019.

13. Nehara HR, Gupta BK, Parmar S, Kumar V, Sihag D, Beniwal S. Antithyroid drug-induced pancytopenia followed by acute lymphoblastic leukemia: A rare case. Thyroid Res Pract. 2020;17:149-51. https://doi.org/10.4103/trp_45_20.

14. Azizi F. The safety and efficacy of antithyroid drugs. Expert opinion on drug safety. 2006;5:10716. https://doi.org/10.1517/14740338.5.1.107.

15. Scappaticcio L, Bellastella G, Maiorino MI, Longo M, Catalano C, Esposito K, et al. Graves' hyperthyroidism-related pancytopenia: a case report with literature review. Hormones. 2021;20:93100. https://doi.org/10.1007/s42000-020-00227-5.

16. Lima CS, Wittmann DE, Catro V, Tambascia MA, Lorand-Metaz I, Saad ST, et al. Pancytopenia in untreated patients with Graves' disease. Thyroid. 2006;16:403-

9. https://doi.org/10.1089/thy.2006.16.403.

17. Soeki T, Tamura Y, KONDO N, Shinohara $H$, Tanaka H, Bando K, et al. A case of thyrotoxicosis with pancytopenia. Endocr J. 2001;48:385-9. https://doi.org/10.1507/endocrj.48.385.

18. Rafhati AN, See CK, Hoo FK, Badrulnizam LB. A report of three cases of untreated Graves' disease associated with pancytopenia in Malaysia. Electron Physician. 2014;6:87782. https://doi.org/10.14661/2014.877-882.

19. Kebapcilar L, Yeşil S, Bayraktar F, Saklamaz A, Demir T, Gungor O, et al. Recovery from pancytopaenia and liver dysfunction after administration of propylthiouracil for Graves' disease. N Z Med J. 2005 
Aug 12;118(1220):U1615.

\section{Tables}

Table 1: Laboratory data of the patient

\begin{tabular}{|c|c|c|c|c|c|c|}
\hline & $\begin{array}{l}\text { At } \\
\text { diagnosis }\end{array}$ & $\begin{array}{l}14 \text { months } \\
\text { later }\end{array}$ & $\begin{array}{l}22 \text { months later (on } \\
\text { admission) }\end{array}$ & $\begin{array}{l}\text { Day } \\
3\end{array}$ & $\begin{array}{l}\text { Day } \\
7\end{array}$ & $\begin{array}{l}\text { Day } \\
14\end{array}$ \\
\hline $\begin{array}{l}\mathrm{TSH}(0.4-4 \\
\mathrm{mU} / \mathrm{L})\end{array}$ & 0.005 & 95.89 & 0.005 & - & - & - \\
\hline $\begin{array}{l}\mathrm{FT} 4(0.9-2.3 \\
\mathrm{ng} / \mathrm{dl})\end{array}$ & 30 & 0.01 & 19.5 & - & - & - \\
\hline $\begin{array}{l}\text { FT3 }(1.4-4.2 \\
\mathrm{pg} / \mathrm{ml})\end{array}$ & - & 0.01 & 31.0 & - & - & - \\
\hline $\begin{array}{l}\text { Hemoglobin } \\
(\mathrm{g} / \mathrm{dl})\end{array}$ & 12.9 & - & 17.4 & 14.9 & 14.0 & 7.9 \\
\hline $\operatorname{MCV}(80-100 \mathrm{fl})$ & 83 & & 85.6 & 84.8 & 82.9 & 84.3 \\
\hline WBC $\left(10^{3} / \mathrm{L}\right)$ & 8.4 & - & 1.50 & 1.40 & 1.50 & 1.40 \\
\hline $\operatorname{ANC}\left(10^{3} / \mathrm{L}\right)$ & 3.3 & - & 0.21 & 0.49 & 0.14 & 0.30 \\
\hline $\operatorname{ALC}\left(10^{3} / \mathrm{L}\right)$ & 3.9 & - & 1.27 & 0.91 & 1.37 & 1.10 \\
\hline Platelet $\left(10^{3} / \mathrm{L}\right)$ & 295 & - & 20 & 22 & 52 & 53 \\
\hline RBC (million/L) & 3.6 & - & 5.1 & - & - & - \\
\hline $\mathrm{Na}^{+}(\mathrm{mmol} / \mathrm{l})$ & 141 & - & 135 & 136 & 132 & 129 \\
\hline $\mathrm{K}^{+}(\mathrm{mmol} / \mathrm{l})$ & 4.1 & - & 3.7 & 3.6 & 3.0 & 3.7 \\
\hline $\mathrm{Ca}^{+2}(\mathrm{mg} / \mathrm{dl})$ & 8.7 & - & 7.8 & 8.3 & 8.5 & 8.8 \\
\hline $\left.\mathrm{PO}^{-2} 9 \mathrm{mg} / \mathrm{dl}\right)$ & - & - & 3.9 & 2.8 & 3.1 & 2.6 \\
\hline $\begin{array}{l}\text { Uric Acid } \\
(\mathrm{mg} / \mathrm{dl})\end{array}$ & - & - & 2.6 & 2.9 & 3.1 & 2.5 \\
\hline $\begin{array}{l}\text { Creatinine } \\
(\mathrm{mg} / \mathrm{dl})\end{array}$ & 0.3 & - & 0.2 & 0.2 & 0.3 & 0.2 \\
\hline $\begin{array}{l}\text { Bilirubin } \\
(\mathrm{mg} / \mathrm{dl})\end{array}$ & 0.9 & - & 0.7 & - & - & - \\
\hline AST/ALT (U/L) & $32 / 25$ & - & $35 / 29$ & - & - & - \\
\hline
\end{tabular}


ALC= Absolute lymphocyte count, ALT = Alanine transferase, ANC $=$ Absolute neutrophil count, AST= Aspartate transferase, $\mathrm{FT} 3=$ Free tri-iodothyronine, $\mathrm{FT} 4=$ Free thyroxine, $\mathrm{RBC}=$ Red cell count, $\mathrm{TSH}=$ Thyroid stimulating hormone, WBC= White cell count. 